\title{
Inositol and Glucocorticoid in the Development of Lung Stability in Male and Female Rabbit Fetuses ${ }^{1}$
}

\author{
MAURIZIO M. ANCESCHI, ADRIANO PETRELLI, GIUSEPPE ZACCARDO, \\ ANTONELLA BARBATI, GIAN CARLO DI RENZO, ERMELANDO V. COSMI, AND \\ MIKKO HALLMAN \\ Institute of Gynecology and Obstetrics, University Perugia, Policlinico Monteluce, Perugia, Italy and Department \\ of Pediatrics, University of Helsinki, Helsinki, Finland [M.H.]
}

\begin{abstract}
Inasmuch as inositol affects the development of lung surfactant, and exogenous glucocorticoids accelerate fetal lung maturation, a possible interaction of the two substances on alveolar stability of preterm rabbit fetuses of 28 days gestation was investigated. On days 26 and 27 of gestation inositol or glucose were added to the diet of does treated with betamethasone $(0.2 \mathrm{mg} / \mathrm{kg}$ intramuscularly on days 26 and 27). Inositol increased lung-thorax compliance of paralyzed fetuses at all insufflation pressures studied (from 16 to 22.5 and $30 \mathrm{~cm} \mathrm{H} \mathrm{H}_{2} \mathrm{O}$ and back to 22.5 , and $16 \mathrm{~cm} \mathrm{H}_{2} \mathrm{O}$ ). At a ventilation pressure of $30 \mathrm{~cm}$ $\mathrm{H}_{2} \mathrm{O}$, lung-thorax compliance of fetuses treated with inositol plus betamethasone was more than doubled as compared with controls $(1.2 \pm 0.6$ versus $0.5 \pm 0.2 \mathrm{ml} / \mathrm{kg} \times$ $\mathrm{cm} \mathrm{H}_{2} \mathrm{O} ; p<0.001$ ). Inositol alone had no detectable effect on compliance, whereas betamethasone tended to increase compliance $(p=0.05)$. According to variance analysis, the effect of inositol was statistically significant only among the males. Inositol prevented the glucocorticoid-induced decrease in lung protein and, to a lesser extent, the decrease in DNA. Inositol did not further increase the lavageable surfactant pool of the glucocorticoid-treated, ventilated fetuses, although the area occupied by lamellar bodies within type II cells was increased after inositol plus betamethasone. According to the present study, inositol modifies the physiologic and biochemical response of the immature fetal lung to a pharmacologic dose of exogenous glucocorticoid. (Pediatr Res 24: 617-621, 1988)
\end{abstract}

\section{Abbreviations}

BM, betamethasone

BW, body weight

RDS, respiratory distress syndrome

The physiologic role of glucocorticoids in fetal lung maturation is widely acknowledged $(1,2)$. Exogenous glucocorticoids accel-

Received February 26, 1988; accepted July 19, 1988.

Correspondence Mikko Hallman, M.D., Department of Pediatrics, Stenbäckinkatu 11, University of Helsinki, SF-00290 Helsinki, Finland.

Supported by the National Research Council (CNR), Progetto Finalizzato Medicina Preventiva e Riabilitativa, Grant 86.00436 .04 and Ministero Pubblica Istruzione, Fondi $40 \%$ (Italy), and by the Finnish Academy, and the Jusélius Foundation (Finland). This work was submitted by M.M.A. in partial fulfillment of requirements for the Ph.D. degree in Perinatology, Department of Obstetrics and Gynecology, University of Perugia, Italy.

A portion of this research was presented at the Annual Meeting of the Society for Pediatric Research, May 1987, Anaheim, CA. erate the maturation of the lung in various species (3-5) and prevent the RDS $(6,7)$. However, the magnitude of the effect on surfactant synthesis $(8,9)$ and secretion $(10,11)$ and particularly on the incidence of $\operatorname{RDS}(6,11)$ is variable and not consistent with the notion that surfactant is the sole structure controlling lung maturity. Males exhibit a delay in fetal lung maturity and, according to some studies, a lack of responsiveness to glucocorticoid $(6,12)$. An additional poorly understood effect of exogenous glucocorticoids is the inhibition of lung growth $(2,5,13)$.

In apparent contradiction to the proposed role of phosphatidylglycerol as an index of fetal lung maturity, addition of inositol supplement (known to suppress phosphatidylglycerol) (14-18) to the feeds of glucocorticoid-treated pregnant rabbits increased surfactant in alveolar lavage from fetuses (19). Furthermore, inositol added to the hormone-supplemented culture medium of fetal lung explants increased the synthesis of surfactant phosphatidylcholine (19).

Our investigation was undertaken in an attempt to clarify some of the controversies concerning the role of glucocorticoid in the development of the fetal lung. We evaluated whether exogenous glucocorticoid and/or inositol alters lung stability in the preterm fetus and whether the effect of these treatments depends on fetal sex.

\section{MATERIALS AND METHODS}

Animals. Experiments were performed on 31 healthy pregnant New Zealand White rabbits weighing between 3.5 and $4.5 \mathrm{~kg}$, whose mating time was known to within $\pm 3 \mathrm{~h}$. Each rabbit was randomly assigned to the four treatment groups (group 1: seven does; group 2: seven; group 3: eight; and group 4: nine).

Protocol. On days 26 and 27 of gestation (day of mating $=0$; term $=31) \mathrm{BM}$ disodium phosphate (Bentelan, Glaxo) $(0.2 \mathrm{mg} /$ $\mathrm{kg}$ ) was injected intramuscularly into the does of groups 3 and 4 and an equal volume of saline $(0.25 \mathrm{ml} / \mathrm{kg})$ into the animals of groups 1 and 2. Before BM and saline injections, $8 \%$ (wt/vol) inositol, $5 \mathrm{ml} / \mathrm{kg}$, was infused intravenously during $5 \mathrm{~min}$ into the animals of groups 2 and 4, and glucose in the same fashion into the animals of groups 1 and 3. Starting from the time of the injection, glucose (groups 1 and 3) and inositol (groups 2 and 4) was added to drinking water at a concentration of $4 \%$ (wt/vol). Otherwise the animals received an ordinary laboratory food (Type C1, Spigadoro, Perugia, Italy) ad libitum.

Lung-thorax compliance measurements. On day 28 of gestation rabbits were anesthetized with $50 \mathrm{mg} / \mathrm{kg}$ of ketamine hydrochloride (Ketalar, Parke Davis), and the newborns were delivered under local anesthesia with $2 \%$ mepivacaine hydrochloride (Carbocaine, Pierrel). A fetus was injected intraperitoneally with 0.1 mg of pancuronium bromide (Pavulon, Organon), delivered by 
hysterotomy, blotted and weighed. A tracheal cannula was secured in the fetal trachea through a tracheostomy. Within 3-5 min from the delivery the fetus was attached to a body plethysmograph kept at $37^{\circ} \mathrm{C}$, and a new fetus was delivered. The fetus was ventilated with $100 \% \mathrm{O}_{2}$ at a frequency of 40 cycles/min and an inspiration/expiration ratio of 5:6 with no end expiratory pressure for a total period of about $5 \mathrm{~min}$. Insufflation pressures were changed every $60 \mathrm{~s}$ from "low" $\left(16,22.5 \mathrm{~cm} \mathrm{H}_{2} \mathrm{O}\right)$ to "high" values $\left(30 \mathrm{~cm} \mathrm{H} \mathrm{H}_{2} \mathrm{O}\right)$ and back to low again $(22.5$ and $16 \mathrm{~cm}$ $\mathrm{H}_{2} \mathrm{O}$ ), in sequence. Tidal volume was continuously recorded by means of a Fleisch tube connected to the pletysmograph, a differential pressure transducer (DBF Engineering, Rome, Italy) and a multichannel recorder (Physiograph, Houston, TX). The respirator generated a square pressure wave and a plateau was reached at end-inspiration. Lung-thorax compliance was calculated by dividing the tidal volume by the insufflation pressure, and expressed on the basis of BW.

Biochemical analyses. After the period of artificial ventilation, the fetuses were killed by intracerebral injection of sodium pentobarbital. A total of 33 fetuses from the different treatment groups was killed after hysterotomy without ventilation. The lungs were lavaged in situ four times with saline $(40 \mathrm{ml} / \mathrm{kg})$; the chest was opened and blood samples withdrawn by heart puncture; the lungs were carefully excised, freed from contaminating tissues, and blotted with filter paper. Blood samples and lungs were stored at $-20^{\circ} \mathrm{C}$ until analysis. Serum inositol of does and their litters was measured as the trimethylsilyl derivative, using gas liquid chromatography, as described previously (19). Lung tissues were homogenized in ice-cold $0.05 \%$ Triton X-100 (wt/ vol, 1:4) with a tissue blender (Polytron, Kinematika, Switzerland) for $60 \mathrm{~s}$, and aliquots taken for protein, DNA, and phospholipid determinations.

Proteins were measured with the method of Bradford (20), using bovine serum albumin as standard, and DNA by the diphenylamine method of Burton (21) with fetal calf thymus DNA as standard.

Phospholipids were extracted from the homogenized tissues by the method of Bligh and Dyer (22) and lipid phosphorus determined according to Ames and Dubin (23). Disaturated phosphatidylcholine in lung lavage was extracted by the method of Bligh and Dyer (22), separated by the method of Mason et al. (24) and measured by a modification of the enzymatic method of Muneshighe et al. (25), using 3,5-dichloro-2-hydroxybenzenesulfonic acid (Aldrich Chemie, Steinheim, W. Germany) as dye reagent. To assess the recovery, $0.01 \mu \mathrm{Ci}\left[{ }^{3} \mathrm{H}\right]$ dipalmitoylphosphatidylcholine tracer (New England Nuclear, Boston, MA) was added to each sample before extraction.

Histology and electron microscopy. At the end of the period of artificial ventilation, three fetuses selected at random from each treatment group were studied for lung morphology. The mean lung-thorax compliance of these fetuses fell within $\pm 0.2 \mathrm{SD}$ of the means shown in Figure 1. The thorax was opened and the lung inflated with air to $20 \mathrm{~cm} \mathrm{H}_{2} \mathrm{O}$. The pressure was decreased to $10 \mathrm{~cm} \mathrm{H} \mathrm{H}_{2} \mathrm{O}$ while the lungs were perfused for $15 \mathrm{~min}$ via the pulmonary artery with a mixture of $1 \%$ glutaraldehyde and $3.5 \%$ formaldehyde in phosphate buffer, $\mathrm{pH}$ 7.3. The perfused lungs were excised and stored in the same fixative until processing. The paraffin sections of the lungs were oriented from apex to base and $5-\mu \mathrm{m}$ sections taken anterior to posterior. After hematoxylin-eosin staining, 10 randomly selected fields were pointcounted from apex to base on multiple sections. A field was rejected if it contained bronchi or large vessels. A standard morphometric method (26) was used to determine ratios of lung interstitium to air space. Two lungs from a glucose plus BMtreated male and a female and two lungs from an inositol plus BM-treated male and female were further processed for electron microscopy. The tissues were postfixed with aqueous osmium tetroxide $(2.0 \% \mathrm{wt} / \mathrm{vol})$, then dehydrated with increasing concentrations of acetone, and embedded in Epon. The thin sections were mounted on copper grids, stained with uranyl acetate, and lead citrate, and then examined in an electron microscope. Electron micrographs of type II alveolar cells, visualized in sections passing through the nucleus and basal and luminal sides of the cell, were photographed at $8500 \times$ magnification. The areas of glycogen patches were estimated by point counting. The cell surface and lamellar body areas were measured with an image analyzer (Kontron, Munich, FRG).

Statistical analysis. Data were analyzed using the BMPD

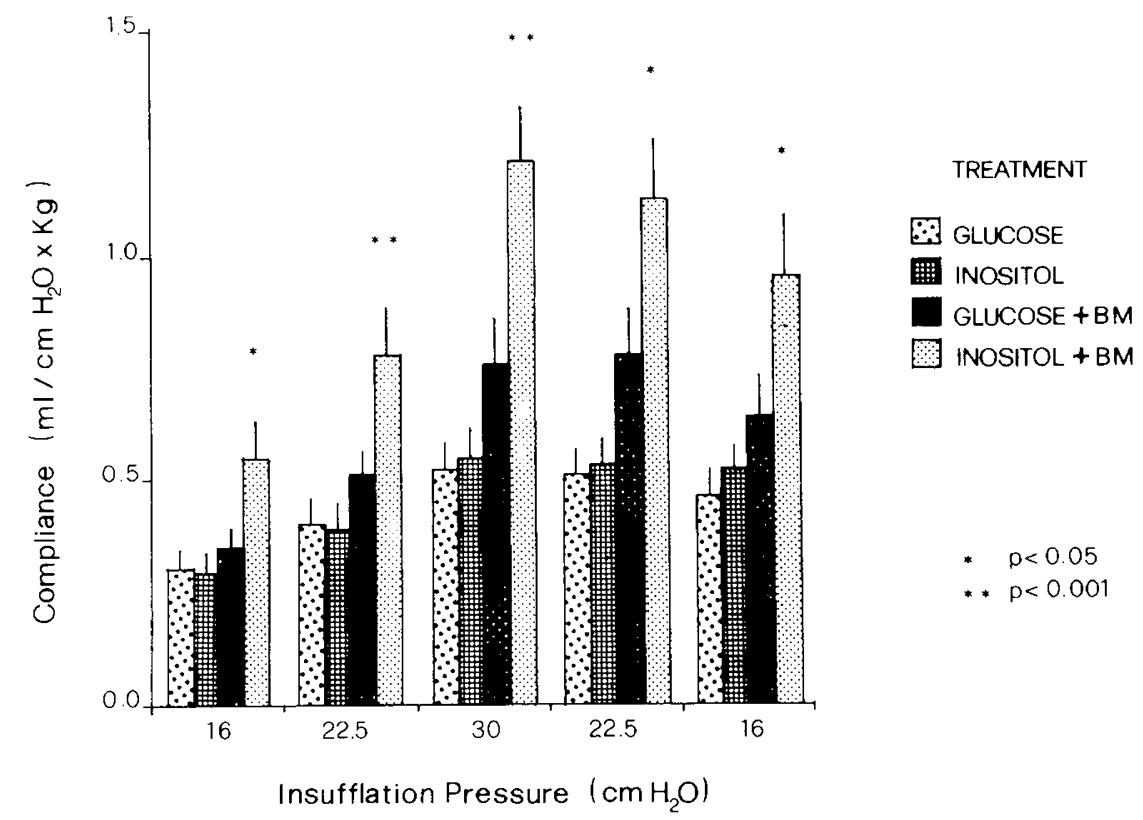

Fig. 1. Lung-thorax compliance $\left(\mathrm{ml} / \mathrm{cm} \mathrm{H}_{2} \mathrm{O} \times \mathrm{kg}\right.$ ) of the four different treatment groups. Animals were ventilated for a total period of $5 \mathrm{~min}$ after birth at insufflation pressures changing every minute from low to high and back to low again (see "Materials and Methods"). Pressures used are shown on the abscissa from the left following the same chronologic order. Each bar represents a different treatment. Values are expressed as means \pm SE. Asterisks indicate statistical significance between inositol + BM versus glucose $\pm \mathrm{BM}$. 
(Biomedical Data Processing) statistical software (University of California press, Berkeley, CA) programs 7D and $4 \mathrm{~V}$. The results, unless otherwise stated, were expressed as means \pm SD. Unless otherwise indicated, the difference between the various treatment groups was evaluated using two-way analysis of variance. The significance of the difference between individual groups was studied using Tukey Studentized range method.

\section{RESULTS}

The 31 pregnant rabbits had altogether 164 live fetuses. There was no difference in litter size between the four treatment groups.

Serum inositol. Inositol supplementation increased serum inositol both in does (glucose + saline: $89.6 \pm 37.9 \mu \mathrm{M}, n=3$; inositol + saline: $295.5 \pm 127.0 \mu \mathrm{M}, n=3$; glucose + BM: 46.8 $\pm 18.7 \mu \mathrm{M}, n=4$; inositol + BM: $183 \pm 157.0 \mu \mathrm{M}, n=4)$ and in fetuses (glucose + saline: $240 \pm 78 \mu \mathrm{M}, n=8$; inositol + saline $706.0 \pm 202.0 \mu \mathrm{M}, n=8$; glucose + BM: $213.4 \pm 105.1 \mu \mathrm{M}, n$ = 19; inositol + BM: $459.8 \pm 342.0 \mu \mathrm{M}, n=27)$. At least one fetus in each litter was analyzed. There were no detectable sex differences in serum inositol. The glucose given to the does did not affect either the inositol or the glucose levels (data not shown).

Lung-thorax compliance. To avoid overdistension of the lungs, measurements were made using a positive end expiratory pressure of zero. When inspiratory pressure was changed from low $\left(16,22.5 \mathrm{~cm} \mathrm{H}_{2} \mathrm{O}\right)$ to high $\left(30 \mathrm{~cm} \mathrm{H}_{2} \mathrm{O}\right)$, and back to low $(22.5$ and $16 \mathrm{~cm} \mathrm{H}_{2} \mathrm{O}$ ) again, there was a good correlation between each five consecutive values of lung thorax compliance $(r>0.90)$ (Table 1). In all groups the compliance increased when the insufflation pressure was increased from 16 to $30 \mathrm{~cm} \mathrm{H}_{2} \mathrm{O}$ (Fig. 1). The compliances observed during the latter part of the ventilation with declining insufflation pressures were higher than the compliances recorded in the early part of the ventilation period, when the insufflation pressure was increasing $(p<0.02)$. This increase in compliance was higher in the BM-treated fetuses (63 $\pm 3 \%$ ) than in the controls $(48 \pm 3 \%, p<0.05$, rank sum test). The order of delivery had no effect on compliance values.

According to variance analysis, $\mathrm{BM} \pm$ inositol $(p<0.01)$ and inositol $\pm \mathrm{BM}(p<0.05)$ had a significant effect on compliance (Table 2). Additionally, there was a significant interaction between the effects of BM and inositol $(p<0.05)$. Both the individual five and the mean of these five compliances gave similar results. The effects of inositol $(p=0.01), \mathrm{BM}(p<$ $0.0001)$, and their interaction $(p=0.02)$ were highest at the insufflation pressure of $30 \mathrm{~cm} \mathrm{H}_{2} \mathrm{O}$. As shown in Figure 1, inositol alone had no effect on compliance. However, when given together with BM, inositol significantly increased the compliance $(p<0.001)$. BM alone tended to increase the compliance as compared to the nonglucocorticoid groups $(p=0.05)$ (Table 3$)$.
The absolute values of lung-thorax compliance $\left(\mathrm{ml} / \mathrm{cm} \mathrm{H}_{2} \mathrm{O}\right.$ ) were analyzed. According to these figures, inositol + BM significantly increased compliance $(p<0.05)$, whereas saline $+\mathrm{BM}$ had no significant effect (data not shown).

Effect of fetal sex. We also evaluated lung-thorax compliance/ $\mathrm{kg}$ wt for possible sex-related difference. In the absence of inositol supplementation, the individual means of the compliances were higher for females than for males. However, the difference between the sexes was not statistically significant. Inasmuch as females that are located between two male fetuses in utero develop similarly to males (12), these female fetuses were excluded in the following analysis. Table 1 shows the lung-thorax compliance of the four groups divided by sex, at an insufflation pressure of $30 \mathrm{~cm} \mathrm{H}_{2} \mathrm{O}$. In males treated with inositol $+\mathrm{BM}$, the compliance was higher than in any other group, whereas in females there was no detectable difference between inositol + $\mathrm{BM}$ and glucose + BM-treated animals. Multivariate analysis of compliances revealed no interaction between sex and the glucocorticoid ( \pm inositol) effect $(p=0.78)$. However, the interaction between sex and the inositol $( \pm \mathrm{BM})$ effect was almost significant $(p=0.06)$. Variance analysis using inositol treatment $( \pm \mathrm{BM})$ and sex as dependent variables revealed a significant interaction between treatment and sex $(p=0.04)$. According to the Duncan multiple range test, the inositol treated males had a higher mean compliance than the glucose-treated males $(p=0.05)$.

Lung lavage $D P C$. The effect of inositol on lavageable surfactant pools was studied by measuring the DPC content of lung lavage fluids. As shown in Table 2, inositol plus BM increased lavageable DPC in fetuses that had not breathed. At the end of the artificial ventilation, no difference was observed in lung

Table 2. Effects of inositol and BM on amount of disaturated phosphatidylcholine (DPC) in lung lavage at birth and after artificial ventilation*

\begin{tabular}{|c|c|c|c|c|}
\hline & & 2 & & \\
\hline Treatment & $\begin{array}{c}1 \\
\text { Glucose } \\
+ \text { saline }\end{array}$ & $\begin{array}{c}\text { Inositol } \\
+ \\
\text { saline }\end{array}$ & $\begin{array}{c}3 \\
\text { Glucose } \\
+ \text { BM }\end{array}$ & $\begin{array}{c}4 \\
\text { Inositol } \\
+\mathrm{BM}\end{array}$ \\
\hline
\end{tabular}

Lung lavage DPC (nmol/animal)

At birth

$$
\begin{array}{cccc}
21 \pm 8 & 24 \pm 7 & 28 \pm 7 & 40 \pm 1 \dagger \\
(7) & (7) & (9) & (10)
\end{array}
$$

After artificial ventilation

$28 \pm 1127 \pm 4 \quad 56 \pm 20 \ddagger 59 \pm 25 \S$

(6) (6) (9)

$*$ Values are means \pm SD for number of determinations in parentheses.

$\dagger p<0.05$ versus 2 and 3 .

$\ddagger p<0.05$ versus 1 .

$\S p<0.05$ versus 2 .

\begin{tabular}{|c|c|c|c|c|}
\hline Treatment & $\begin{array}{c}1 \\
\text { Glucose } \\
+ \text { saline }\end{array}$ & $\begin{array}{c}2 \\
\text { Inositol } \\
+ \text { saline }\end{array}$ & $\begin{array}{c}3 \\
\text { Glucose } \\
+ \text { BM } \\
\end{array}$ & $\begin{array}{c}4 \\
\text { Inositol } \\
+\mathrm{BM} \\
\end{array}$ \\
\hline Males & $\begin{array}{c}0.47 \pm 0.26 \\
\quad(13)\end{array}$ & $\begin{array}{c}0.60 \pm 0.23 \\
(9)\end{array}$ & $\begin{array}{c}0.73 \pm 0.42 \\
(13)\end{array}$ & $\begin{array}{c}1.30 \pm 0.57 \uparrow \ddagger \\
(13)\end{array}$ \\
\hline Females & $\begin{array}{c}0.57 \pm 0.31 \\
\quad(11)\end{array}$ & $\begin{array}{l}0.50 \pm 0.27 \\
\quad(11)\end{array}$ & $\begin{array}{c}0.84 \pm 0.47 \\
(13)\end{array}$ & $\begin{array}{c}1.10 \pm 0.59 \ddagger \\
(11)\end{array}$ \\
\hline Females, those between males excluded & $\begin{array}{c}0.60 \pm 0.24 \\
(8)\end{array}$ & $\begin{array}{c}0.45 \pm 0.21 \\
(9)\end{array}$ & $\begin{array}{c}0.95 \pm 0.39 \S \\
\text { (11) }\end{array}$ & $\begin{array}{c}1.10 \pm 0.59 \ddagger \\
\text { (11) }\end{array}$ \\
\hline
\end{tabular}

Table 1. Lung-thorax compliance $\left(\mathrm{ml} / \mathrm{cm} \mathrm{H}_{2} \mathrm{O} \times \mathrm{kg}\right)$ at insufflation pressure of $30 \mathrm{~cm} \mathrm{H}_{2} \mathrm{O}$; influence of sex*

* Values are expressed as means $\pm \mathrm{SD}$ for number of animals in parentheses.

$\dagger p<0.05$ versus 3 .

$\ddagger p<0.02$ versus 1 and 2 .

$\S p<0.05$ versus 2 . 
lavage DPC between fetuses treated with glucose plus BM and with inositol plus BM. In both groups, however, the lavageable pools were higher than in non-BM-treated fetuses $(p<0.05)$.

Body weight and lung growth. As shown in Table 3, BM significantly decreased fetal body weight. There was a concomitant decrease in total lung DNA and phospholipid. However, inositol supplementation partially prevented the BM-induced decrease in lung protein. Inasmuch as total BW was lower in the BM-treated fetuses, lung proteins, DNA, and phospholipid were adjusted for $\mathrm{BW}$. The lung protein $/ \mathrm{g} \mathrm{BW}$ was higher $(p<0.01)$ in fetuses treated with inositol plus BM not only with respect to glucose plus BM, but also when compared to glucose plus salinetreated controls. Inositol $\pm \mathrm{BM}$ increased the DNA content/g BW when compared with glucose plus saline-treated animals $(p$ $<0.01$ ).

Lung morphology. The lungs from saline ( \pm inositol)-treated animals had prominent interstitium; this was associated with localized nonhomogeneous aeration. However, lungs from glucocorticoid-treated animals, especially those that additionally were exposed to inositol, revealed homogenous aeration and wide air spaces. Morphometric analysis showed the following interstitium-to-air-space rations: group 1: $1.3 \pm 0.4$; group 2: 1.2 \pm 0.5 : group 3: $0.82 \pm 0.30(p<0.05$ versus 1$)$; group 4: $0.48 \pm$ $0.20(p<0.05$ versus 1,2 , and 3$)$.

Altogether 80 randomly selected type II cells were studied. There was no difference in the number of cells in sections of lungs from fetuses of rabbits treated with inositol $+\mathrm{BM}$ and of animals treated with glucose \pm BM. Nor was there a detectable difference in the area occupied by type II cells, or the percentage area occupied by glycogen patches within the type II cells (Table 4). Within a single type II cell, however, both the number and the area occupied by lamellar bodies were significantly higher in lungs from fetuses treated with inositol + BM.

\section{DISCUSSION}

The present study indicates that dietary inositol modifies the physiologic and biochemical response of the immature fetal lung to pharmacologic doses of exogenous glucocorticoids. In the absence of BM, inositol supplementation at least doubled fetal serum inositol, but failed to improve the lung-thorax compliance. Glucocorticoid given alone resulted in a barely detectable increase in the compliance. However, when given together, inositol and BM produced a clear-cut improvement in compliance and decreased interstitium-to-air space ratios, suggesting homogenous expansion of alveoli.

There are several possible mechanisms that explain the ob- served synergism between glucocorticoid and inositol. Exogenous glucocorticoid decreased the energy-independent uptake of inositol into the fetal lung (27). Therefore it is possible that the extra inositol is required to offset the glucocorticoid-dependent decrease in inositol uptake in immature lung. The suggested functions of inositol include stimulation of the glucose-6-phosphate dehydrogenase pathway (19), which provides the NADPH required for endogenous fatty acid synthesis (28). Furthermore, inositol is rate-limiting for the synthesis of phosphatidylinositol, which may activate CTP phosphocholine cytidylyltransferase, an enzyme limiting the rate of surfactant phosphatidylcholine synthesis (29). Inositol additionally may activate of the phosphoinositide cycle and protein kinase C (30), known to promote growth and differentiation (31).

According to recent evidence, the improved lung stability after glucocorticoid was not associated with an increase in the lavageable surfactant pool (32, but see Ref. 33). Additional factors, other than surfactant, may influence neonatal lung stability. These include alveolar capillary permeability (34), composition and microstructure of alveolar surfactant (35) or the connective tissue of the lung (36-38). In our study, inositol + glucocorticoid increased lavageable surfactant in the fetus. However, after the brief period of ventilation, there were no detectable differences in surfactant pools between the two groups of glucocorticoidtreated animals (Table 2), despite a consistent difference in lungthorax compliance. However, the number of lamellar bodies in the type II cells of fetuses treated with inositol + glucocorticoid and ventilated tended to be higher than after glucose plus glu-

Table 4. Morphometric analysis of type II cells

\begin{tabular}{lcc}
\hline \multicolumn{1}{c}{ Treatment } & $\begin{array}{c}\text { Glucose }+\mathrm{BM} \\
(n=42)\end{array}$ & $\begin{array}{c}\text { Inositol + BM } \\
(n=38)\end{array}$ \\
\hline Cell surface area $\left(\mu \mathrm{m}^{2}\right)$ & $64.7 \pm 2.4$ & $65.1 \pm 2.1$ \\
$\begin{array}{l}\text { Area of lamellar bodies/cell } \\
\left(\mu \mathrm{m}^{2}\right)\end{array}$ & $1.8 \pm 0.7$ & $2.6 \pm 0.6^{*}$ \\
$\begin{array}{l}\text { Area of glycogen patches/ } \\
\text { cell }\left(\mu \mathrm{m}^{2}\right)\end{array}$ & $14.7 \pm 4.9$ & $12.8 \pm 4.4$ \\
$\begin{array}{l}\text { No. of lamellar bodies/sec- } \\
\text { tion of cell }\end{array}$ & $3.4 \pm 0.7$ & $5.3 \pm 1.3 \dagger$ \\
\hline
\end{tabular}

$* p<0.05$ as compared with glucose $+\mathrm{BM}$.
$\dagger p<0.01$ as compared with glucose $+\mathrm{BM}$.

Table 3. Effects of inositol and BM on BW and total lung proteins, phospholipids, and DNA*

\begin{tabular}{|c|c|c|c|c|}
\hline Treatment & $\begin{array}{c}1 \\
\text { Glucose } \\
+ \text { saline } \\
\end{array}$ & $\begin{array}{c}2 \\
\text { Inositol } \\
+ \text { saline } \\
\end{array}$ & $\begin{array}{c}3 \\
\text { Glucose } \\
+\mathrm{BM} \\
\end{array}$ & $\begin{array}{c}4 \\
\text { Inositol } \\
+\mathrm{BM}\end{array}$ \\
\hline $\mathrm{BW}(\mathrm{g})$ & $\begin{array}{c}38.7 \pm 6.4 \\
(34)\end{array}$ & $\begin{array}{c}35.4 \pm 5.6 \\
(33)\end{array}$ & $\begin{array}{c}31.4 \pm 4.1 \dagger \\
(49)\end{array}$ & $\begin{array}{c}31.9 \pm 3.1 \dagger \\
(47)\end{array}$ \\
\hline Lung proteins (mg) & $\begin{array}{c}72.1 \pm 13.8 \\
(34)\end{array}$ & $\begin{array}{c}73.0 \pm 14.9 \\
(33)\end{array}$ & $\begin{array}{c}60.5 \pm 10.9 \ddagger \\
(39)\end{array}$ & $\begin{array}{c}67.4 \pm 13.2 \\
(36)\end{array}$ \\
\hline Lung DNA (mg) & $\begin{array}{c}4.5 \pm 0.7 \\
\quad(24)\end{array}$ & $\begin{array}{c}5.0 \pm 0.8 \\
(26)\end{array}$ & $\begin{array}{c}4.2 \pm 0.7 \ddagger \\
(35)\end{array}$ & $\begin{array}{l}4.1 \pm 0.6 \neq \\
\quad(35)\end{array}$ \\
\hline Lung phospholipid ( $\mu \mathrm{mol})$ & $\begin{array}{c}13.5 \pm 3.0 \\
(33)\end{array}$ & $\begin{array}{c}13.0 \pm 4.2 \\
(36)\end{array}$ & $\begin{array}{c}11.3 \pm 1.7 \S \\
(36)\end{array}$ & $\begin{array}{c}11.2 \pm 1.9 \S \\
(35)\end{array}$ \\
\hline
\end{tabular}

\footnotetext{
$*$ Values are means \pm SD for numbers of observations in parentheses.

$\dagger p<0.01$ versus 1 and 2 .

$\ddagger p<0.05$ versus 1 and 2 .

$\S p<0.01$ versus 1 .
} 
cocorticoid, suggesting an increase in intracellular surfactant and/or a decrease in ventilation-induced exocytosis of surfactant. The possibility that the hormone-inositol interaction produced a decrease in alveolar-capillary permeability, or a change in lung connective tissue, remains to be studied.

In vivo studies have indicated that the response to exogenous glucocorticoids is sex-specific, with females responding better than males $(6,39)$, and that the phenomenon is androgen dependent (12). According to our results, inositol supplementation reversed the so-called "male disadvantage" in fetal lung maturation, since the inositol treatment of males tended to increase the compliance whereas this failed to occur in females (Table 1). Although intriguing, the mechanism of action of inositol, possibly counteracting the negative effect of androgens, remains elusive. As an approach to studying the mechanism of sexual dimorphism, avian fetuses with reversed sex karyotypes were found to have a male instead of a female advantage in the sexspecific response to glucocorticoid and androgen (12). The lack of surfactant phosphatidylglycerol even in an adult avian species (40) suggests exceptionally high alveolar inositol. There are population-based differences found in human sexual dimorphism of fetal lung maturation $(6,7)$. Therefore, the possibility that inositol is a determinant of the sex difference in surfactant synthesis deserves further consideration.

According to the present (Table 3 ) and the previous study (19), inositol modified the abnormal glucocorticoid-induced pattern of fetal lung growth toward normal. However, it failed to correct for the decrease in body weight or the decrease in lung DNA and total lung phospholipid after glucocorticoid. Besides inositol, there are other nutrients, growth factors, and hormones $(8,9)$ that modify the glucocorticoid-induced perturbation in lung growth and the glucocorticoid-induced alteration in the timing of lung differentiation. A more complete understanding of the underlying mechanisms is required to maximize the effectiveness and safety of glucocorticoid in preventing RDS.

\section{REFERENCES}

1. Huemmelink R, Ballard PL 1986 Endogenous corticoids and lung development in the fetal rabbit. Endocrinology 118:1622-1629

2. Smith BT, Bogues WG 1980 Effect of drugs and hormones on lung maturation in experimental animals and man. Pharmacol Ther 9:51-74

3. Anderson GG, Lamden MP, Cidlowski JA, Ashikaga T 1981 Comparative pulmonary surfactant-inducing effect of three corticosteroids in the near term rat. Am J Obstet Gynecol 139:562-564

4. De Lemos RA, Shermaeta DW, Knelson JH, Kotas RV, Avery ME 1970 Acceleration of appearance of pulmonary surfactant in the fetal lamb by administration of corticosteroids. Am Rev Respir Dis 102:459-461

5. Kotas RV, Avery ME 1971 Acceleration appearance of the pulmonary surfactant in the fetal rabbit. J Appl Physiol 30:358-361

6. Collaborative Group on Antenatal Steroid Therapy 1981 Effect of antenatal dexamethasone administration on the prevention of respiratory distress syndrome. Am J Obstet Gynecol 141:276-287

7. Liggins GC, Howie RN 1973 Prevention of respiratory distress syndrome by antepartum corticosteroid therapy. In: Foetal and Neonatal Physiology. University Press, Cambridge, pp 613-617

8. Gross I, Wilson CM, Ingelson LD, Brehier A, Rooney SA 1980 Fetal lung in organ culture. III. Comparison of dexamethasone, thyroxine, and methylxantines. J Appl Physiol 48:872-877

9. Mendelson CM, Johnston JM, Mac Donald PC, Snyder JM 1981 Multihormonal regulation of surfactant synthesis by human fetal lung in vitro. $\mathrm{J}$ Clin Endocrinol Metab 53:307-317

10. Kitterman JA, Liggins GC, Campos GA, Clements JA, Forster CS, Lee CH, Creasy RK 1981 Prepartum maturation of the lung in fetal sheep: relation to cortisol. J Appl Physiol 51:384-390
11. Liggins GC, Howie RN 1972 A controlled trial of antepartum clucocorticoid treatment for prevention of RDS in premature infants. Pediatrics 50:515525

12. Torday JS, Nielsen HC 1987 The sex difference in fetal lung surfactant production. Exp Lung Res 12:1-9

13. Carson SH, Taeusch HW, Avery ME 1973 Inhibition of lung cell division after hydrocortisone injection in fetal rabbits. J Appl Physiol 34:660-665

14. Batenburg JJ, Klazinga W, Van Golde LMG 1982 Regulation of phosphatidylglycerol and phosphatidylinositol synthesis in alveolar type II cells isolated from adult rat lung. FEBS Lett 147:171-174

15. Beppu OS, Clements JA, Goerke J 1983 Phosphatidylglycerol deficient lung surfactant has normal properties J Appl Physiol 55:496-502

16. Bleasdale JE, Snyder JM, Johnson RL 1986 Structure and function of phosphatidylglycerol deficient lung surfactant. Lung 164:339-353

17. Bleasdale JE, Tyler NE, Busch FN, Quirk JG 1983 The influence of myoinositol on phosphatidylglycerol synthesis by rat type II pneumonocytes. Biochem J 212:811-818

18. Hallman M, Epstein BL 1980 Role of myo-inositol in the synthesis of phosphatidylglycerol and phosphatidylinositol in the lung. Biochem Biophys Res Commun 92:1151-1159

19. Hallman M 1984 Effect of extracellular myo-inositol on surfactant phospholipid synthesis in the fetal rabbit lung. Biochim Biophys Acta 795:67-78

20. Bradford MM $1976 \mathrm{~A}$ rapid and sensitive method for the quantitation of microgram quantities of protein utilizing the principle of protein-dye binding. Anal Biochem 72:248-254

21. Burton K 1956 A study of the conditions and mechanism of diphenylamine reaction for the colorimetric estimation of deoxyribonucleic acid. Biochem J 62:315-323

22. Bligh EG, Dyer WJ 1959 A rapid method of total lipid extraction and purification. Can J Biochem Physiol 37:911-917

23. Ames BN, Dubin DT 1960 The role of polyamines in the neutralization of bacheteriophage deoxyribonucleic acid. J Biol Chem 235:769-775

24. Mason RJ, Nellenbogen I, Clements JA 1976 Isolation of disaturated phosphatidylcholine with osmium tetroxide. J Lipid Res 17:281-284

25. Muneshige A, Okazaki T, Quirk JG, MacDonald PC, Nozaki M, Johnston JM $1983 \mathrm{~A}$ rapid and specific enzymatic method for the quantification of phosphatidylcholine and phosphatidylglycerol in amniotic fluid. Am Obstet Gynecol 145:474-480

26. Weibel ER 1979 Stereological Methods, Vol I. Academic Press, New York, pp 33-58

27. Hallman M, Slivka S, Wozniak P, Sills J 1986 Perinatal development of myoinositol uptake into lung cells: surfactant and phosphatidylglycerol and phosphatidylinositol synthesis in the rabbit. Pediatr Res 20:179-185

28. Maniscalco WM, Finkelstein JM, Parkhurst AP 1982 De novo fatty acid synthesis in developing rat lung. Biochim Biophys Acta 11:49-58

29. Feldman DA, Kovac CR, Dranginis PL, Weinhold PA 1978 The role of phosphatidylglycerol in the activation of CTP: phosphocholine cytidylyltransferase from rat lung. J Biol Chem 253:4980-4986

30. Hallman M, Romu M 1987 Evidence of the role of protein kinase C in perinatal development of the surfactant synthesis. Pediatr Res 21:214(abstr)

31. Nishizuka Y 1986 Studies and perspectives of protein kinase C. Science 233:305-312

32. Ikegami I, Jobe A, Pettenazzo A, Seidner SR, Berry DD, Ruffini LD 1987 Effect of combination of maternal hormone treatments on lung function of preterm rabbits. Pediatr Res 21:455(abstr)

33. Smith BT 1984 Pulmonary surfactant during fetal development and neonatal adaptation: hormonal control. In: Robertson B, Van Golde LMG, Batenburg JJ (eds) Pulmonary Surfactant. Elsevier, Amsterdam, pp 357-381

34. Jobe A, Ikegami M, Jacobs H, Jones S, Conaway D 1983 Permeability of premature lamb lungs to protein and the effect of surfactant on that permeability. J Appl Physiol 55:169-176

35. Baritussio A, Magoon MW, Goerke J, Clements JA 1981 Precursor-product relationship between rabbit type II cell lamellar bodies and alveolar surfaceactive material. Biochim Biophys Acta 666:382-393

36. Mitzner W, Johnson JWC, Scott R 1979 Effect of betamethasone on pressurevolume relationships of fetal monkey lung. J Appl Physiol 47377-382

37. Schellenberg JC, Liggins GC, Stewart AW 1987 Growth, elastin concentration, and collagen concentration of perinatal rat lung: effects of dexamethasone Pediatr Res 21:603-607

38. Schellenberg JC, Liggins GC, Kitterman JA, Lee CCH 1987 Elastin and collagen in the fetal sheep lung. II Relationship to mechanical properties of the lung. Pediatr Res 22:339-343

39. Kotas RV, Avery ME 1980 The influence of sex on fetal rabbit lung maturation and on the response to glucocorticoid. Am Rev Resp Dis 121:377-380

40. Hallman M, Gluck L 1976 Phosphatidylglycerol in lung surfactant. III. Possible modifier of surfactant function. J Lipid Res 17:257-262 